\title{
Corona Virus Disease 2019 Pandemic: Strengthening the Prevention and Control Activities in the American Region
}

\author{
Saurabh Shrivastava, ${ }^{1}$ (D) Prateek Shrivastava ${ }^{2}$
}

'Department of Community Medicine, Member of the Medical Education Unit and Institute Research Council, Shri Sathya Sai Medical College \& Research Institute, Sri Balaji Vidyapeeth Deemed to be University, Ammapettai, Nellikuppam, Chengalpet District, Tamil Nadu, India ${ }^{2}$ Department of Community Medicine, Shri Sathya Sai Medical College \& Research Institute, Sri Balaji Vidyapeeth - Deemed to be University, Ammapettai, Nellikuppam, Chengalpet District, Tamil Nadu, India

Please cite this article as: Shrivastava S, Shrivastava P. Corona Virus Disease 2019 Pandemic: Strengthening the Prevention and Control Activities in the American Region. Anatol J Family Med 2020;3(3):260-261.

Address for correspondence: Dr. Saurabh Shrivastava. Department of Community Medicine, Member of the Medical Education Unit and Institute Research Council, Shri Sathya Sai Medical College \& Research Institute, Sri Balaji Vidyapeeth - Deemed to be University, Ammapettai, Nellikuppam, Chengalpet District, Tamil Nadu, India

Phone: +919884 227224

E-mail:

drshrishri2008@gmail.com

Received Date: 26.05.2020

Accepted Date: 09.06.2020

Published online: 04.11.2020

(C) Copyright 2020 by Anatolian Journal of Family Medicine -

Available online at www.anatoljfm.org

OPEN ACCESS

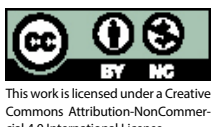

\section{ABSTRACT}

The ongoing Corona Virus Disease-2019 (COVID-19) outbreak has been spreading across the world at a rapid pace and has raised serious objections about the level of preparedness of the nations and their ability to mobilize resources to implement an emergency response. To date, the American region as a whole has reported 1636841 cases and 91893 deaths across 35 nations and 19 territories. The need of the hour is to take prompt steps, which will aid the nations to reorganize the delivery of health care services and simultaneously safeguard the safety of health professionals. There is a significant need to strengthen the facilities for promoting early case detection, isolation of the suspect or confirmed cases, care for the patients, and contact tracing. However, the most critical element involves the citizens in the disease control by improving their awareness about the disease, motivating them to practice respiratory and hand hygiene, and maintaining social distancing by avoiding unnecessary travel or recreation. In conclusion, the COVID-19 pandemic has emerged as a global health emergency and affected even the American region as a whole, considering the number of nations and territories which have reported the cases. However, we have to be really dedicated to our approach and ensure that we succeed in implementing a comprehensive emergency response strategy.

Keywords: COVID-19 pandemic, United States, World Health Organization

\section{INTRODUCTION}

\section{Global Scenario}

The ongoing Corona Virus Disease-2019 (COVID-19) outbreak has been spreading across the world at a rapid pace and has raised serious objections about the level of preparedness of the nations and their ability to mobilize resources to implement an emergency response. ${ }^{[1]}$ The global estimates depict that 6663304 cases and 392802 deaths have been reported across 216 nations and territories, with an overall case fatality rate of $5.9 \% \cdot{ }^{[1]}$ The disease, which has been first detected in a single city in China, has eventually spread to all the continents. ${ }^{[1]}$ However, it is worth noting that regardless of any other attributes, all the global population, nations and continents are very much susceptible to acquisition of the infection and 
only better preparedness and comprehensive emergency response can effectively contain the novel infection which has already attained pandemic status. ${ }^{[1,2]}$

\section{COVID-19 Estimates: American Region}

To date, the American region as a whole has reported 3155370 cases and 176167 deaths across 35 nations and 19 territories. ${ }^{[1]}$ The region has surpassed all the regions and is currently the most affected one. It is important to note that the case fatality rate in the region is $5.6 \%$, while concerning caseload, the Unites States of America alone accounts for $58.87 \%$ of the caseload in the American region. ${ }^{[1]}$ Among the affected territories, Puerto Rico has reported the highest number of cases and deaths, and it is the need of the hour not to relax but to stay focused and dedicated towards the implementation of prevention and control efforts. ${ }^{[1,3,4]}$

\section{Proposed Measures: Preparedness and Emergency Response}

The need of the hour is to take prompt steps, which will aid the nations to reorganize the delivery of health care services and simultaneously safeguard the safety of health professionals, as they are in the forefront against this novel disease and very much exposed to the risk of acquiring the infection. ${ }^{[3,4]}$ Further, there is a significant need to strengthen the facilities for promoting early case detection, isolation of the suspect or confirmed cases, care for the patients, strict adherence to the International Health Regulations at the point of entry and contact tracing. ${ }^{[4,5]}$ In addition, the domains of risk communication, infection prevention \& control, community engagement and maintenance of supply chain management of logistics needs to be further improved ${ }^{[4]}$ However, the most critical element is involving the citizens in the disease control by improving their awareness about the disease, motivating them to practice respiratory and hand hygiene, and maintaining social distancing by avoiding unnecessary travel or recreation. ${ }^{[3-7]}$

It is important to acknowledge that even now, that the epidemic curve of the disease can be flattened, but it will obviously require concerted support from all the stakeholders. ${ }^{[3]}$ If we do not act now, the number of cases is bound to increase as no one is immune to the infection, and that will definitely jeopardize the functioning of the health care delivery system. ${ }^{[3]}$ Further, we also have to understand that many of the nations have limited capacity and capabilities to deal with the infection, and it is always better to accelerate the efforts now instead of doing mitigation related activities after the disease goes out of control. ${ }^{[2-5]}$

\section{CONCLUSION}

In conclusion, the COVID-19 pandemic has emerged as a global health emergency and affected even the American region as a whole, considering the number of nations and territories which have reported the cases. However, we should be really dedicated to our approach and ensure that we succeed in implementing a comprehensive emergency response strategy.

\section{Disclosures}

Peer-review: Externally peer-reviewed.

Conflict of Interest: None declared.

Authorship contributions: Concept - S.R.S.; Design - S.R.S., P.S.S.; Supervision - S.R.S., P.S.S.; Analysis and/or interpretation S.R.S., P.S.S.; Literature search - P.S.S.; Writing - S.R.S.; Critical Review - S.R.S., P.S.S.

\section{REFERENCES}

1. WHO. Coronavirus disease 2019 (COVID-19) Situation Report - 138. Available at: https://www.who.int/docs/defaultsource/coronaviruse/situation-reports/20200606-covid19-sitrep-138.pdf?sfvrsn=c8abfb17_4. Accessed Jun 7, 2020.

2. Tanne JH, Hayasaki E, Zastrow M, Pulla P, Smith P, Rada AG. Covid-19: how doctors and healthcare systems are tackling coronavirus worldwide. BMJ 2020;368:m1090. \{CrossRef]

3. WHO. PAHO Director to Health Ministers - "Reorganize health services to care for COVID-19 patients and save lives". Available at:https://www.paho.org/hq/index.php?option=com_conten t\&view=article\&id=15758:paho-director-to-health-ministersreorganize-health-services-to-care-for-covid-19-patientsand-save-lives\&catid=740\&lang=en\&ltemid=1926. Accessed May 26, 2020.

4. WHO. 2019 Novel Coronavirus (2019-nCoV): Strategic preparedness and response plan. Geneva: WHO press; 2020. p. $1-3$.

5. Jernigan DB; CDC COVID-19 Response Team. Update: Public Health Response to the Coronavirus Disease 2019 Outbreak - United States, February 24, 2020. MMWR Morb Mortal Wkly Rep 2020;69:216-9. \{CrossRef]

6. Haider N, Yavlinsky A, Simons D, Osman AY, Ntoumi F, Zumla $A$, et al. Passengers' destinations from China: low risk of Novel Coronavirus (2019-nCoV) transmission into Africa and South America. Epidemiol Infect 2020;148:e41 \{CrossRef]

7. Wilder-Smith A, Freedman DO. Isolation, quarantine, social distancing and community containment: pivotal role for oldstyle public health measures in the novel coronavirus (2019nCoV) outbreak. J Travel Med 2020;27(2):taaa020. [CrossRef] 